\title{
The Construction Wage Stabilization Program
}

This study investigates the effect of the Construction Industry Stabilization Committee (CISC) on negotiated unionized construction settlements between 1971 and 1973. ${ }^{1}$ The results suggest that the CISC reduced negotiated settlements directly by its presence and indirectly through mitigating wage interdependencies, as speculated by D. Q. Mills. After a review of Mills' tentative findings, estimates of a model incorporating wage interdependence and CISC presence are presented, and the direct and indirect components of the CISC effect are estimated.

\section{CISC and Wage Interdependency}

Mills presented tentative evidence that the CISC was effective in moderating negotiated construction settlements. ${ }^{2}$ In addition to variables representing market forces, his wage model includes a variable measuring the variance of the wage packages over the preceding three years for 22 trades in each of 52 cities, in an attempt to capture the effect of interdependent wage settlements. The underlying premise is that distortions in the wage structure generate a "catch-up process" by other crafts, increasing the area's level of construction wages. ${ }^{3}$ In Mills' work this variable was positive and significant.

*Assistant Research Scientist, CRED, University of Michigan, Ann Arbor.

${ }^{1}$ Helpful suggestions on this paper were received from Professor D. Q. Mills of MIT and Professors Francis McLaughlin, Donald White, and Geoffrey Woglom of Boston College. Research was conducted with support from the U.S. Department of Labor, Manpower Dissertation Grant number DL-91-2575-11. Mr. Joe Russell, formerly Executive Secretary of the CISC, kindly assisted with the preparation of the CISC data.

${ }^{2}$ Daniel Q. Mills, "Explaining Pay Increases in Construction, 1953-1972," Industrial Relations, XIII (May, 1974), 196-201. The CISC was formed in March 1971 and given responsibility to review negotiated settlements; the committee disbanded in June 1974.

${ }^{3}$ Mills cites the example of plumbers and other crafts in Wilmington, Delaware, using the pipefitters' large settlement (1970) to justify their increased demands in 1971. Ibid., p. 197.

Industrial Relations, Vol. 17, No. 3 (October 1978) ${ }^{\circ} 1978$ by The Regents of the University of California. $0019-8676 / 78 / 1025 / 308 \$ 1.00$ 
Mills included a dummy variable for the presence of the CISC in the negotiating process. This variable was negative and significant, leading him to conclude that the CISC directly reduced negotiated construction settlements. Mills also suggested that the CISC might have indirectly depressed wage settlements by reducing the variance in negotiated settlements, but noted that this relationship was not conclusively shown. To examine the CISC program more rigorously, he suggested developing an equation explaining wage structure which incorporated a dummy variable reflecting the existence of controls. ${ }^{4}$

\section{The Wage Model}

The model developed here uses CISC data and includes variables representing market forces and those capturing wage interdependence. The market forces are: the area's all-civilian unemployment rate (a proxy for local construction labor supply conditions); the percentage change in the marginal value product of construction labor (a proxy for local construction labor demand conditions); 5 an area strike index measuring days lost per construction work stoppage; and the percentage change in the local consumer price index.

Each equation also includes the lagged value of the craft's own wage change, the lagged wage changes of other crafts within the bargaining area, and the largest lagged wage change of the same craft within the geographic area. The craft's own lagged wage change should negatively affect the current wage change due to a potential erosion of bargaining power following a large wage change. Also, many contracts are of two-year duration, calling for a substantial increase in the first year, but a smaller one in the second. The past wage changes of other area crafts should affect positively the craft's current settlement, as a result of wage interdependence. The industry's decentralized bargaining structure invites the duplication of a substantial increase by other crafts in the following year. Wage changes among like crafts can be transmitted between neighboring cities. Cities experiencing substantial demand-induced settlements can transmit these

\footnotetext{
${ }^{4}$ Ibid., p. 200 .

In a competitive situation an increase in the marginal value product of labor - an outward shift in the labor demand function - will increase the equilibrium wage with any inelasticity associated with the labor supply. Assuming constant returns to scale and having estimates of an industry production function, differentiation of the MVPL function and appropriate algebraic substitution gives a measure for changes in the MVPL. This measure isolates shifts in the labor demand function (resulting from technological progress, changes in capital stock, or changes in output price) from movements along a downward sloping demand function. A rigorous derivation of this measure is available from the author on request. The other markel variables were used in slightly different form by Mills in a 1968 cross-section study. See Daniel Q. Mills, Industrial Relations and Manpower in Construction (Cambridge, MA.: MIT Press, 1971).
} 
settlements to cities where the level of construction activity does not justify them. The variable measuring the largest lagged wage change of the same craft within the region tests this geographic interdependence. ${ }^{6}$

A separate wage equation for each of three crafts-electricians, iron workers, and plumbers - is estimated, using 200 observations (annual wage changes 1961-1970 from 20 cities). ${ }^{7}$ The results presented in Table 1 confirm the importance of both market forces and wage interdependencies. ${ }^{8}$ The unemployment rate and strike index are significant for the iron workers and the plumbers. For each craft the CPI coefficient is significant and is not statistically different from one. The labor demand variable is significant only for the electricians. ${ }^{9}$ The craft's own lagged wage change is negative and significant for the iron workers and plumbers. Wage interdependencies are shown with the electricians' settlements raised by the lagged settlement of the iron workers and the plumbers; with those of the iron workers raised by the lagged settlement of the plumbers; and with those of the plumbers raised by the lagged settlement of the electricians. The geographic wage interdependency term is significant for the electricians and the iron workers.

CISC effects. One procedure to examine the effect of the CISC on negotiated settlements is to extend the time-series to include the 1971-1972 and 1972-1973 settlements, to add a dummy variable signifying the presence of the CISC in those settlements, and to re-estimate the model. The signs and significance of the coefficients in these re-estimated equations are very similar to those found in the original equations. ${ }^{10}$ The only notable exception is that the geographic interdependency terms for the electricians and iron workers are no longer significant. The CISC dummy variable is negative and highly significant for each craft. The estimated coefficients suggest that the CISC directly reduced negotiated settlements by $3.8,2.6$, and 3.5 per cent for the electricians, iron workers, and plumbers, respectively. Further, the CISC indirectly reduced settlements by mitigating the


Estimation problems with that number of independent variables prevent such a specification.

${ }^{7}$ The cities are: Philadelphia, Pittsburgh, New York, Newark, Boston, Baltimore, Washington, D.C., Houston, Atlanta, Milwaukee, Cincinnati, Cleveland, Kansas City, St. Louis, Minneapolis, Chicago, Detroit, Seattle, San Francisco, and Los Angeles.

${ }^{8}$ These equations, containing lagged dependent variables as explanatory influences, were tested with the Hildreth-Lu estimating technique and Cooper transformation. The first order serial correlation coefficients did not differ significantly from zero; $F$ tests of the transformed equations allowed rejection of the null hypothesis of no additional explanatory power from the interdependency terms. Also tested was a model that included lagged values of the independent market influences. However, the craft wage interdependency terms continued to be significant, supporting their influence on wage settlements.

${ }^{9}$ The imprecision of the industry capital stock values, as well as an inability to incorporate changes in the composition of demand (residential to nonresidential), complicate the testing of this variable.

${ }^{10}$ For the electricians, iron workers, and plumbers respectively, the estimated CISC dummy coefficients with their $t$ values were as follows: $-.038(-5.54),-.026(-3.41)$, and $-.035(-4.54)$. The re-estimated equations are available from the author on request.
} 


\section{Construction Wage Stabilization Program / 311}

TABLE I

Wage Settlement Regression Results, 1961/62 - 1970/71

\begin{tabular}{|c|c|c|c|}
\hline \multirow[b]{2}{*}{ Independent variable } & \multicolumn{3}{|c|}{$\%$ change in wage/fringe package } \\
\hline & Electricians & Iron workers & Plumbers \\
\hline Constant & $\begin{array}{l}.013^{\#} \\
(1.29)\end{array}$ & $\begin{array}{l}.045^{* *} \\
(4.02)\end{array}$ & $(2.81)^{* 0}$ \\
\hline Area all-civilian unemployment rate & $\begin{array}{l}-.155 \\
(-.98)\end{array}$ & $\begin{array}{c}-.321^{\circ \%} \\
(-1.70)\end{array}$ & $\begin{array}{c}-.241^{*} \\
(-1.33)\end{array}$ \\
\hline $\begin{array}{l}\% \text { change in the area cost of living } \\
\text { (preceding settlement) }\end{array}$ & $\begin{array}{l}.85^{\circ \circ} \\
(3.84)\end{array}$ & $\begin{array}{l}1.19^{* *} \\
(4.27)\end{array}$ & $\begin{array}{c}1.27^{\circ} \\
(5.01)\end{array}$ \\
\hline $\begin{array}{l}\text { Index of local strike activity } \\
\text { (year of settlement) }\end{array}$ & $\begin{array}{l}.0005 \\
(.83)\end{array}$ & $\begin{array}{l}.002^{*} \\
(2.12)\end{array}$ & ${ }_{(1.35)}^{.0009^{\circ}}$ \\
\hline $\begin{array}{l}\% \text { change in the area marginal } \\
\text { value product of labor } \\
\text { (preceding settlement) }\end{array}$ & $(1.70)$ & $\begin{array}{l}-.009 \\
(-.43)\end{array}$ & $\begin{array}{l}-.005 \\
(-.24)\end{array}$ \\
\hline $\begin{array}{l}\text { Lagged \% wage change of } \\
\text { electricians }\end{array}$ & $\begin{array}{l}.023 \\
(.27)\end{array}$ & $\begin{array}{l}.055 \\
(.55)\end{array}$ & $\begin{array}{l}.315^{\circ \%} \\
(3.27)\end{array}$ \\
\hline $\begin{array}{l}\text { Lagged } \% \text { wage change of } \\
\text { iron workers }\end{array}$ & $(2.72)$ & $\begin{array}{l}-.271^{*} \\
(-3.28)\end{array}$ & $\begin{array}{l}.047 \\
(.61)\end{array}$ \\
\hline $\begin{array}{l}\text { Lagged } \% \text { wage change of } \\
\text { plumbers }\end{array}$ & $(2.95)$ & $\begin{array}{l}.170^{\circ 6} \\
(2.23)\end{array}$ & $\begin{array}{l}-.169^{\circ 0} \\
(-2.08)\end{array}$ \\
\hline $\begin{array}{l}\text { Largest lagged \% wage change } \\
\text { within region of electricians }\end{array}$ & $(1.89)$ & & \\
\hline $\begin{array}{l}\text { Largest lagged } \% \text { wage change } \\
\text { within region of iron workers }\end{array}$ & & $\begin{array}{l}.116^{\circ} \\
(1.54)\end{array}$ & \\
\hline $\begin{array}{l}\text { Largest lagged } \% \text { wage change } \\
\text { within region of plumbers }\end{array}$ & & & $\begin{array}{l}.071 \\
(.96)\end{array}$ \\
\hline $\mathbf{F}$ & $31.10^{\circ 0}$ & $18.81^{\circ \%}$ & $23.00^{\circ \circ}$ \\
\hline $\mathbf{R}^{2}$ & .57 & 44 & .49 \\
\hline D.W. (adjusted for 19 gaps) & 1.93 & 1.96 & 2.09 \\
\hline $\operatorname{SSR}(n=200)$ & .188 & .261 & .252 \\
\hline
\end{tabular}

$t$-statistics in parenthesis

- significant at .10 level.

* significant at .05 level.

effects of wage interdependence. Current craft settlements are affected by lagged craft settlements. Thus, the CISC by reducing the current settlement of a craft, reduces the future settlements of crafts whose wage changes are influenced by that lagged settlement. The magnitude of these effects, both direct and indirect, are investigated below.

\section{Some Further Tests}

Two related procedures are employed to further specify the effects of the CISC. First, the actual and predicted mean wage changes for the three crafts are compared during the 1971-1973 period, a procedure 
followed by Perry in evaluating wage guideposts. ${ }^{11}$ Secondly, simulation experiments with the equations presented in Table 1 can separate the direct and indirect effects of the CISC.

Table 2 compares the actual and predicted wage changes for each craft during the control period. Actual increases were those approved by the CISC. Predicted increases were generated by substituting the published values for the market influences in the equations shown in Table 1. The actual 1970-1971 wage changes are used as the lagged wage changes in the 1971-1972 equations. However, the predicted 1971-1972 increases were substituted as the lagged values in the 1972-1973 equations. The mean actual and predicted wage changes for the 1971-1973 period, years of CISC monitoring, are shown below for the 20 cities. In all six cases the predicted increases exceeded the actual increases. Tests with the standard error of the regression allowed rejection of the hypotheses of equal predicted and actual increases at .10 significance.

TABLE 2

Mean Actual and Predicted Settlements

\begin{tabular}{lccc|ccc}
\hline \hline & \multicolumn{3}{c|}{$1971-1972$} & \multicolumn{3}{c}{$1972-1973$} \\
\cline { 3 - 6 } & Actual & Fitted & Residual & Actual & Fitted & Residual \\
\hline Electricians & .066 & .128 & -.062 & .049 & .093 & -.044 \\
Iron workers & .074 & .096 & -.022 & .049 & .081 & -.032 \\
Plumbers & .067 & .110 & -.043 & .050 & .094 & -.044 \\
\hline
\end{tabular}

The argument for CISC effectiveness can be strengthened by showing the mechanism by which CISC action limited wage increases. The following equation divides the total effect of CISC action $\left(\mathrm{CISC}_{i, t}\right)$ into the direct effect of its presence and the indirect effect of reducing wage interdependencies:

$$
\begin{aligned}
\mathrm{CISC}_{i, t}= & \mathrm{D}_{\mathbf{i}}+\mathrm{b}_{\mathbf{i}}\left(\mathrm{w}_{\mathrm{i}, \mathrm{t}-1}^{\mathrm{a}}-\mathrm{w}_{\mathrm{i}, \mathrm{t}-1}^{\mathrm{p}}\right)+\mathrm{b}_{\mathbf{j}}\left(\mathrm{w}_{\mathbf{j}, \mathrm{t}-1}^{\mathrm{a}}-\mathrm{w}_{\mathbf{j}, \mathrm{t}-1}^{\mathrm{p}}\right)+ \\
& \mathrm{b}_{\mathrm{k}}\left(\mathrm{W}_{\mathrm{k}, \mathrm{t}-1}^{\mathrm{a}}-\mathrm{w}_{\mathrm{k}, \mathrm{t}}^{\mathrm{p}}-\mathrm{l}\right) .
\end{aligned}
$$

where CISC $_{i, t}=$ the total effect of the CISC on craft i's wage change in time $\mathrm{t}$

$D_{i}=$ the direct effect of the CISC on craft i's wage change; whose values correspond to the estimated CISC dummy coefficients

\footnotetext{
${ }^{11}$ Two criticisms of Perry's approach by Wachter should be kept in mind. First, Quandt and F tests do not allow rejection of the hypothesis of a stable wage relationship during the estimating period for the equations in Table 1 . Wachter considered this a necessary statistical condition. Secondly, Wachter suggested that an explanation of how the policy affects wages should be given. See George Perry, "Wages and the Guideposts," American Economic Review, LVII (September, 1967), 897-905; and Michael Wachter, "Wages and the Guideposts: Comment," American Economic Review, LIX (June, 1969), $354-358$.
} 
$\mathrm{W}_{\mathrm{i}, \mathrm{t}}=$ the wage change of craft $\mathrm{i}$ in time $\mathrm{t}$; $a$ implies actual and $p$ predicted change

$b_{i}=$ the appropriate coefficient of a lagged wage change on a craft's current settlement (see Table 1).

With this equation the total CISC effect can be empirically measured for each of the two years considered. Since CISC wage monitoring began in March 1971, only the 1971-1972 settlements would be affected directly by the CISC. All indirect terms would equal zero since the CISC had no effect on the 1970-1971 settlements which comprise the indirect terms in the 1971-1972 equation. A 1972-1973 settlement, however, would not only be directly reduced by the CISC presence, but indirectly reduced by the lower 1971-1972 settlements. Table 2 indicates that the mean nationwide predicted plumbers' settlement for 1971-1972 was .110 while, in fact, the mean plumbers' settlement approved by the CISC was .067. Consequently, the electricians' 1972-1973 settlement, affected by the 1971-1972 plumbers' settlement, was indirectly held down by $-.008=.191(.067-.110)$. Table 3, using the results of Table 2, shows the direct and indirect effect of CISC action in each of the two years, with the percentage of the residual explained by combined effects.

TABLE 3

Mean Direct and Indirect Effects of the CISC

\begin{tabular}{lccc}
\hline \hline & Electricians & Iron workers & Plumbers \\
\hline 1971-1972 & & & \\
$\quad$ Direct effect & -.038 & -.026 & -.035 \\
$\quad \begin{array}{l}\text { Indirect effect } \\
\text { Total effect }\end{array}$ & -.038 & -.026 & 0 \\
$\quad$ Residual & -.062 & -.022 & -.035 \\
$\quad \begin{array}{l}\text { Per cent of residual } \\
\quad \text { explained by total effect }\end{array}$ & 61 & 118 & -.043 \\
$\begin{array}{l}\text { 1972-1973 } \\
\quad \text { Direct effect }\end{array}$ & & & 81 \\
$\quad \begin{array}{l}\text { Indirect effect } \\
\text { Total effect }\end{array}$ & -.038 & -.026 & -.035 \\
$\quad \begin{array}{l}\text { Residual } \\
\text { Per cent of residual } \\
\quad \text { explained by total effect }\end{array}$ & -.014 & -.005 & -.013 \\
\hline
\end{tabular}

\section{Discussion}

For 1971-1972, the total effect is simply the direct effect of the CISC presence; the 1972-1973 settlements, however, are influenced directly and indirectly. For both the electricians and the plumbers, the inclusion of the indirect effect raises the total effect of the CISC by approximately 40 per cent (each settlement is reduced an additional 1.4 per cent). 


\section{4 / CLARK G. ROSS}

For the iron workers, whose settlements are reduced 2-3 per cent by CISC presence, this indirect effect is less substantial. Iron workers' settlements are not so strongly affected by the past settlements of the other crafts (see Table 1). Five of the six residuals are explained in a range between 80 and 120 per cent. An additional indirect effect is the probable reduction in strike activity induced by the CISC. The mean value nationwide for the strike index fell from 3.45 in 1970 to 2.02 in 1971. Since it is not possible to predict the value of the strike index in the absence of the CISC, no empirical test of this proposition is possible.

Since the CISC was disbanded in the spring of 1974, the 1974-1975 settlements provide evidence on post-CISC behavior. The mean 19741975 electricians' settlement was 9.6 per cent and that for plumbers 8.7 per cent; ${ }^{12}$ these equal or exceed settlements predicted by the equations in Table 1. Thus, while the CISC significantly affected wage settlements during its tenure, post-CISC wage behavior reverted to that predicted by the model of wage interdependence. These results suggest that a wage monitoring program in an industry characterized by wage interdependence can succeed in mitigating negotiated settlements.

\footnotetext{
${ }^{12}$ These are mean settlements for cities with 100,000 or more inhabitants. Comparable data were unavailable for the iron workers.
} 